\title{
PENGARUH TERAPI BERMAIN PADA ANAK USIA PRASEKOLAH TERHADAP KEHILANGAN KONTROL DALAM HOSPITALISASI DI RUANG ANAK RSUD NGUDI WALUYO WLINGI
}

\author{
ERNA SUSILOWATI, RITA MEI DWI V \\ AKPER DHARMA HUSADA KEDIRI \\ Ernabudi_80@yahoo.co.id
}

\begin{abstract}
At child in age pre school at first times taken care in hospital, they experienced hospitalization stress. They experience lost control (ancient) and trouble in interaction with environment (nurse, friend and next door patient). The feeling can arouse from to face something new and have never experienced it before, feel balmy and not save. Playing activities as usual have to be Limited, routinely they done daily at home, they can not conduct it at hospital. They way to minimize hospitalization stress with arrangement of environment and perform activity like game. Hence researcher perform a research concerning "Influence of Play Therapy at child in Age of Preschool to Lost Control in Hospitalization ". This research target was to know the influence of play therapy at child in age of pre used school to lost control in hospitalization in child room of RSUD Ngudi Waluyo Wlingi Blitar. Research design pre experiment the types was pre post test design. Its population was all children in age of pre school that experiencing taken care in hospital in child room of RSUD Ngudi Waluyo Wlingi Blitar (25 children age of pre school). Sample taken counted 24 respondents. Use purposive sampling. Appliance and data collecting used observation with checklist. Data analyzed including editing, coding, scoring, tabulating. Research result with 24 respondents, reaction of lost control in hospitalization before giving of play therapy got value 3-4 $(62,5 \%)$ counted is children in bad category. Value 5-7 (37,5\%) counted 9 children with enough category. Reaction of lost control in hospitalization after giving play therapy got value 8-10 (100\%) in good category. From research result can be concluded that change of reaction of control at child in age pre school in hospitalization before and after play therapy in child room RSUD Ngudi Waluyo Wlingi Blitar give influence to lost control in hospitalization so that child become cooperative to the therapy treatment of healing.
\end{abstract}

Key word : Play therapy, lost control (hospitalization process), Child in age of pre school

\section{PENDAHULUAN}

Proses hospitalisasi bagi anak dapat menjadi suatu pengalaman yang menimbulkan trauma baik pada anak maupun orang tua sehingga menimbulkan reaksi tertentu, yang akan sangat berdampak pada kerja sama anak dan orang tua dalam perawatan anak selama di rumah sakit (Supartini, 2004 Sebagaimana dikutip dari Halstroom dan Elander, 1997, Brewis, E, 1995 dan Brennan, A, 1994 : 187). Bermain diyakini mampu untuk menghilangkan berbagai batasan hambatan dalam diri, stress, frustasi, bahkan dapat dipakai untuk terapi bermain. (Sarie, 2002).

Di Indonesia angka kejadian kehilangan kontrol pada anak mencapai $75 \%$ dan hanya $25 \%$ anak mampu mengendalikan kehilangan kontrol, angka ini jauh lebih tinggi di bandingkan dengan negara-negara yang lain. Seperti Amerika Serikat, Jerman dan Kanada. (Judarwanto, 2006). Dan dari hasil studi Studi pendahuluan yang dilakukan di RSUD Ngudi Waluyo Wlingi Blitar tanggal 2325 Februari 2009 di dapatkan data 6 orang ibu dan 3 orang bapak yang anaknya usia prasekolah di rawat diruang anak selama 3 
hari mengatakan anaknya berhenti bahkan ada yang sama sekali tidak beraktifitas atau bedrest total diatas tempat tidur. (10\%) 1 orang ibu yang anaknya usia prasekolah (4 th) mengatakan selama 3 hari dirawat, anak itu ingin cepat pulang kerumah, bermain bersama temantemannya, takut, menangis, tidak mau minum obat, marah ke petugas kesehatan (perawat). Tetapi ibu tersebut setiap anaknya menangis diberi mainan dan akhirnya diam, mau minum obat dan mematuhi perawat. Data diatas menunjukkan bahwa (90\%) anak usia prasekolah yang dirawat diruang anak RSUD Ngudi Waluyo Wlingi Blitar mengalami kehilangan kontrol dalam hospitalisasi dan hanya (10\%) yang terpenuhi kebutuhan bermainnya walaupun tidak optimal.

Para anak-anak terutama mereka yang baru pertama kalinya dirawat dirumah sakit, stressor hospitalisasi terdiri dari perpisahan, perlukaan tubuh dan nyeri, sakit pasti akan merasa stress dan takut serta kehilangan kontrol. Keadaan ini timbul akibat pembatasan fisik, pengurangan rutinitas kegiatan dan adaanya ketergantungan. Mereka rata-rata takut dengan suasana rumah sakit yang asing bagi mereka, karena mereka dalam beraktifitas atau dalam kegiatan yang biasa mereka lakukan tiap hari dirumah tidak dapat mereka lakukan dirumah sakit, karena dalam beraktifitas mereka dibatasi terutama untuk program terapi penyembuhan penyakit dan juga karena tidak adanya fasilitas bermain.

Permainan yang kreatif dapat berfungsi untuk perkembangan imajinasi anak, mengembangkan kemampuan berkomunikasi dan dapat mengekspresikan ide dan perasaan mereka dengan cara yang kreatif. (Anna Craft, 200.h.88).

Anak sakit stresnya akan bertambah karena sakit sendiri sudah merupakan stressor ditambah pula dengan adanya pemasangan infus dan bidai, injeksi setiap hari, minum obat dan lain-lain. Akibat stress yang berlebihan dengan mekanisme koping anak yang kurang maka anak mengalami masalah psikologis yang berat seperti takut, anak menjadi manja dengan orang tua, hiperaktif dan trauma dengan hospitalisasi (Whaley and Wong, 1991.h.105).

Anak sakit stresnya akan bertambah karena sakit sendiri sudah merupakan stressor ditambah pula dengan adanya pemasangan infus dan bidai, injeksi setiap hari, minum obat dan lain-lain. Akibat stress yang berlebihan dengan mekanisme koping anak yang kurang maka anak mengalami masalah psikologis yang berat seperti takut, anak menjadi manja dengan orang tua, hiperaktif dan trauma dengan hospitalisasi (Whaley and Wong, 1991.h.105). Cara-cara meminimalisir stressor hospitalisasi antara lain dengan pengaturan lingkungan, membuat jadwal rutinitas dan mengadakan permainan

\section{Metode Penelitian}

Desain atau rancangan penelitian ini, peneliti menggunakan penelitian eksperimen (Pre-Exsperimen).

Jenis penelitian ini adalah ( $\underline{\text { One- }}$ Group - Pra-Test - Post Test Design). Dalam satu kelompok, adalah mengungkapkan hubungan sebab akibat dengan cara melibatkan satu kelompok subyek. Kelompok subyek diobservasi sebelum dilakukan intervensi, kemudian diobservasi lagi setelah di intervensi. (Nursalam, 2003 : 88) Dalam penelitian kali ini peneliti ingin melakukan suatu perlakuan pada responden yang diambil yaitu anak usia prasekolah yang menjalani rawat inap diruang RSUD Ngudi Waluyo Wlingi Blitar yaitu berupa terapi barmain konstruktif dengan menggunakan alat permainan edukatif (APE). Terapi bermain dilakukan pada responden yang telah diambil dan dipilih oleh peneliti dengan perlakuan terapi bermain sebanyak satu (1) kali perlakuan dan dinilai kehilangan kontrolnya sebelum dan sesudah perlakuan terapi bermain. 
Penelitian ini dilaksanakan pada tanggal 5 Mei sampai dengan 21 Mei 2009, tempat penelitian di RSUD Ngudi Waluyo Wlingi Blitar. Pada penelitian ini populasinya adalah seluruh anak usia prasekolah yang dirawat diruang anak RSUD Ngudi Waluyo Wlingi Blitar berjumlah 25 anak. Penelitian ini menggunakan purposive sampling Variabel independent dalam penelitian ini adalah terapi bermain. Variabel dependent dalam penelitian ini adalah proses kehilangan kontrol dalam hospitalisasi pada anak usia pra sekolah Analisa data menggunakan perangkat SPSS (Statistic Package For The Social Science), dengan uji - T berpasangan

\section{Hasil Penelitian}

Diagram pengaruh reaksi kehilangan kontrol dalam hospitalisasi pada anak usia prasekolah sebelum dan sesudah terapi bermain di Ruang Anak RSUD Ngudi Waluyo Wlingi Blitar pada tanggal 5 Mei - 21 Mei tahun 2009

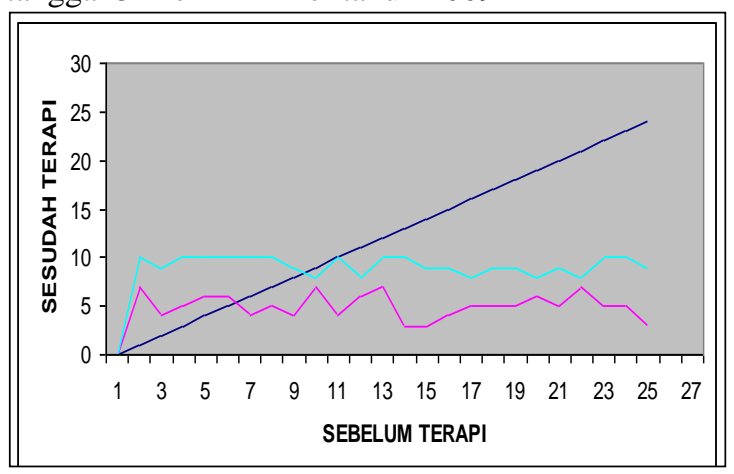

Diagram 1 menunjukkan bahwa adanya pengaruh reaksi kehilangan kontrol dalam proses hospitalisasi pada anak usia prasekolah sebelum dan sesudah pemberian terapi bermain, sebelum diberikan terapi bermain sebagian besar didapatkan nilai 3-5 dalam kategori buruk $(<50 \%)$ sebanyak 15 responden. Sesudah diberikan terapi bermain seluruhnya didapatkan nilai 8-10 dalam kategori baik (75-100\%) sebanyak 24 responden.

Sesudah hasil observasi reaksi kehilangan kontrol sebelum dan sesudah dilakukan terapi bermain didapatkan hasil tersebut kemudian diolah melalui perhitungan SPSS (Statistic Package For
The Social Science), dengan uji -T berpasangan didapatkan mean (selisih rata-rata) $=-4,16667$, std deviation $($ simpangan baku $)=1,12932$. std error mean $($ galat baku rata-rata) $=\mathrm{sd} / \sqrt{n}=1$ : $1293 \mathrm{Z} \sqrt{24}=0.23052$. menggunakan selang kepercayaan $95 \% \quad(-$ 4.64354.3.68980), $\mathrm{T}$ ( $\mathrm{T}$ hitung $)=-18.075$, derajat bebas $(\mathrm{df})=23$ dengan probabilitasnya pada pengujian dua pihak (sig.2-failed) sebesar 0,000.

Karena probabilitasnya lebih kecil dari taraf nyata $\alpha / 2=0,025$, maka Ho ditolak $\mathrm{H}_{1}$ diterima, jadi ada perbedaan antara pengaruh terapi bermain pada anak usia prasekolah terhadap kehilangan kontrol dalam hospitalisasi di ruang anak RSUD Ngudi Waluyo Wlingi Blitar.

\section{Pembahasan}

Berdasarkan data yang diperoleh bahwa responden tidak dapat mengendalikan kehilangan kontrol, karena akibat kurang efektifnya koping perilaku saat menjalani rawat inap sehingga anak mengalami stress psikologis adanya pembatasan fisik, dalam beraktifitas yang biasa mereka lakukan tiap hari dirumah tidak dapat mereka lakukan di rumah sakit.

Perawat harus bisa bekerjasama dengan orang tua maupun keluarga. Karena orang tua dan keluarga sangat membantu dalam mengendalikan kehilangan kontrol dalam hospitalisasi.

Perawatan anak di rumah sakit merupakan pengalaman yang penuh dengan stress, baik bagi anak-anak maupun orang tua. lingkungan rumah sakit itu sendiri merupakan penyebab stress bagi anak dan orang tuanya, baik lingkungan fisik rumah sakit seperti ruang perawatan, alat-alat bau khas, pakaian putih petugas kesehatan maupun lingkungan social, seperti sesama pasien anak, ataupun interaksi dan sikap petugas kesehatan itu sendiri. Perasaan, seperti takut, cemas, tegang, nyeri dan perasaan yang tidak menyenangkan lainnya sering kali dialami anak (Supartini, 2004, 
sebagaimana dikutip (dari Brennan, 1994 : 145). Selain itu antara anak yang sudah sekolah (play group) dan yang belum sekolah itu apa yang diinginkannya sangat berbeda, sehingga perawat harus mengerti permaianan yang disenanginya oleh anakanak sehingga anak lebih kooperatif dan tidak mengalami kontrol dalam hospitalisasi Di ruang anak RSUD Ngudi Waluyo Wlingi Blitar, anak usia prasekolah yang dirawat diberi terapi bermain oleh peneliti yaitu mewarnai, menyusun balok, menyusun puzzel, anak kooperatif dengan instruktur penelitiannya. Secara teoritis bermain sangat bermanfaat untuk dapat mengembangkan kemampuan intelektualnya, meningkatkan daya kreatifitas, merupakan cara untuk mengatasi kemarahannya dan kekhawatiran, anak belajar mengontrol diri, bisa bergaul dengan teman sebaya, adanya interaksi. (Soetjiningsih, 1995).

Pengobservasian responden dilakukan dua kali, pada saat satu hari setelah dilakukan terapi bermain. Dari data yang didapat ternyata terbukti bahwa terapi bermain berpengaruh besar dalam reaksi kehilangan kontrol pada proses hospitalisasi yang dialami pada anak usia prasekolah. Tetapi bermain sangat penting dilakukan karena dapat meningkatkan kepercayaan anak terhadap perawat dan mereka merasa tidak takut lagi dengan berbagai macam tindakan keperawatan. Bagi anak kebutuhan bermain adalah kebutuhan yang sangat penting, ini terbukti dengan anak tidak memisahkan antara bermain dan belajar. Bagi anak bermain merupakan seluruh aktifitas anak termasuk bekerja, kesenangannya dan merupakan metode bagaimana mereka mengenal dunia. Bermain tidak sekedar mengisi waktu, tetapi merupakan kebutuhan anak seperti halnya makanan, perawatan, cinta kasih dan lain-lain. (Soetjiningsih, 1995) Menurut Soetjiningsih (1995) banyak keuntungan yang dipetik dari bermain. Membuang ekstra energi, bermain juga dapat mengoptimalkan pertumbuhan seluruh bagian tubuh seperti tulang, otot dan organ-organ. Aktivitas yang dilakukan dalam permainan tersebut dapat meningkatkan nafsu makan anak. Dari bermain anak-anak tersebut bisa belajar mengontrol diri mereka sendiri. Berkembangnya berbagai ketrampilan yang akan berguna sepanjang hidupnya dan dapat meningkatkan daya kreatifitas anak. Bermain merupakan kegiatan yang luar biasa karena dari bermain bisa mendapat kesempatan menemukan arti dari benda-benda yang ada disekitar anak. Bermain merupakan cara untuk mengatasi kemarahan, kekawatiran, iri hati dan kedukaan. Mereka juga mempunyai kesempatan untuk belajar bergaul dengan anak lainnya, menjadi pihak yang kalah ataupun yang menang di dalam bermain juga, belajar mengikuti aturan-aturan dan bermain juga dapat mengembangkan kemampuan intelektual anak.

Dalam perawatan di rumah sakit memaksa anak untuk berpisah dari lingkungan yang dirasakannya aman. Perawatan di rumah sakit juga membuat anak kehilangan kontrol terhadap dirinya sendiri. Bagi anak yang sakit dan dirawat di rumah sakit, bermain tidak hanya berfungsi untuk kesenangan anak, tetapi dapat menjadi suatu media yang dapat mengekspresikan perasaan cemas, takut, nyeri, dan rasa bersalah. Maka kita dapat mengetahui bahwa dengan bermain anak mampu mengendalikan kehilangan kontrol dalam hospitalisasi dan anak mampu mengurangi kekawatiran dan kedukaan yang dialami oleh mereka.

\section{Kesimpulan dan Saran}

1. Terapi bermain pada anak usia prasekolah mampu mengendalikan kehilangan kontrol dalam hospitalisasi sehingga perawat tidak sulit lagi untuk melakukan asuhan keperawatan dan dokter juga tidak kesulitan untuk melakukan program terapi lainnya.

2. Terapi bermain ternyata dapat mengendalikan stressor psikologis 
yang dialami sebelumnya dan mereka menjadi kooperatif terhadap perawatan.

3. Terapi bermain berperan meningkatkan penyembuhan anak, perkembangan dan pertumbuhan anak.

Peneliti menyarankan agar peran perawat dalam memberikan permainan konstruktif untuk mengurangi stressor hospitalisasi sehingga diharapkan proses penyembuhan berlangsung dengan cepat. Kita sebagai petugas kesehatan harus bekerja sama dengan orang tua maupun keluarga, karena orang tua maupun keluarga merupakan panutan bagi anak dan merekalah orang yang paling dekat dengan anak.

\section{Daftar Pustaka}

Anna, Craft. (2000). Belajar Merawat Anak di Bangsal. EGC : Jakarta

Arikunto Suharsimi. (2002). Prosedur Penelitian Edisi Revisi 5. Rineka Cipta : Jakarta.

Betz And Sowden. (1996). Prinsip Keperawatan Pediatrik. EGC : Jakarta

Delaune and Sowden. (1996). Prinsip Keperawatan Pediatrik. EGC : Jakarta

Friedman, Marlyn M. (1995). Keperawatan Keluarga Teori dan Praktek Edisi 3. EGC: Jakarta

Gayatri Arum. 1990. Kamus Kesehatan. Arcan : Jakarta

Hurlock, Elizabeth B. (1995). Perkembangan Anak. Erlanga : Jakarta

Nursalam, Siti Pariani. (2001). Metodologi Riset Keperawatan Pendekatan Praktisi. CV Agung Setyo : Jakarta
Nursalam. (2003). Konsep dan Penerapan Metodologi Penelitian Ilmu Keperawatan. Salemba Medika : Jakarta

Soetjiningsih. (1995). Tumbuh Kembang Anak. Penerbit Buku Kedokteran. EGC : Jakarta

Suhendi. (2001). Keperawatan Anak di Rumah Sakit. Balai penerbit FKUI : Jakarta

Supartini. (2004). Konsep dasar Keperawatan Anak. EGC : Jakarta

Whaley And Wong. (1991). Konsep Perawatan Pada Pediatri. Penerbit Buku Kedokteran EGC Jakarta 